\title{
Severe Canavan disease
}

INSERM

\section{Source}

INSERM. (1999). Orphanet: an online rare disease and orphan drug data base. Severe Canavan disease. ORPHA:314911

Severe Canavan disease (CD) is a rapidly progressing neurodegenerative disorder characterized by leukodystrophy with macrocephaly, severe developmental delay and hypotonia. 